\title{
Prof. Ananda Mohan Chakrabarty: The Superbug Superhero!
}

\author{
Piyush Pandey ${ }^{1}$. Naveen Kumar Arora ${ }^{2}$
}

Published online: 29 July 2020

(c) Society for Environmental Sustainability 2020

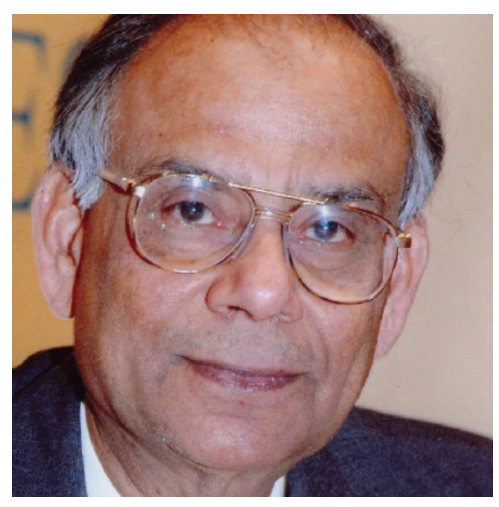

(1938-2020)

Anand Mohan Chakrabarty was a distinguished Indianborn American microbiologist and scientist who became famous for his notable contribution in the field of genetic engineering. With his extraordinary work he has inspired millions of researchers to experiment with microbial genes to utilize them in various fields, bringing in new dimensions to biotechnological aspects of microorganisms. The life of Prof. Ananda Mohan Chakrabarty will always remain an inspiring tale of challenges, and scientific breakthroughs for the coming generations of environmental microbiologists. Prof. Chakraborty is no more amongst us, as he left for heavenly abode on 10th July 2020.

Nandipur (now Sainthia) had been a little-known place in Birbhum district, West Bengal, India, until Prof. Chakrabarty was born there on 4th day of April 1938, to Shri Satya

Piyush Pandey

piyushddn@gmail.com; ppmicroaus@gmail.com

$\triangle$ Naveen Kumar Arora

nkarora.bbau@gmail.com

1 Soil and Environmental Microbiology Lab, Department of Microbiology, Assam University, Silchar, India

2 Department of Environmental Science, Babasaheb Bhimrao Ambedkar University, Lucknow, India
Dos and Smt. Sasthi Bala (Mukherjee) Chakrabarty. He was born in a middle class family and was the youngest among seven children. He completed his schooling at Sainthia High School and Ramakrishna Mission Vidyamandira. Prof. Chakrabarty completed his B. Sc. Degree from St. Xavier's College in 1958, and M. Sc. from Calcutta University, India in 1960. He completed his Ph D. from the Calcutta University itself in 1965 . Soon after his Ph D., he moved to University of Illinois for research assignment (1965-1971); and later joined General Electric Research and Development Center, Schenectady, United States (1971-1979). He was appointed as Professor at the Department of Microbiology, University of Illinois, Chicago in 1979, and continued to serve the same department as Distinguished Professor up to 1989 (Douglas 2015; Renneberg et al. 2017).

In 1971, Prof. Chakrabarty got notable recognition for development of a genetically engineered Pseudomonas, "an oil eating bacteria" also known as "superbug" while working at General Electric Research and Development Center. He invented a method of genetic cross-linking to transfer genes required for degradation of oil using plasmid transfer technique and as a result produced a new stable bacterial species (now known as Pseudomonas putida). He called it as a "multi-plasmid hydrocarbon-degrading Pseudomonas" which was capable of digesting two thirds of hydrocarbons found in typical oil spill and that too faster (about one or two orders of magnitudes) than previously existing strains of oil-eating microbes (https://alliedacademies.com/profile/ AC, https://rootsofindian.wordpress.com/2017/07/15/anand a-mohan-chakrabarty-indian-who-opened-the-floodgates -for-life-patenting/). This discovery became a biological remedy for removing oil pollution especially during disastrous oil spills and leakages in marine ecosystems.

Later, he applied for a patent on this breakthrough technique which was the first ever on any living entity. However, it was initially denied and was then challenged in Court of Customs and Patents Appeals Office and finally in the Supreme Court. Prof. Chakrabarty argued that a living being must not always be naturally occurring and in this case, the bacteria Pseudomonas was genetically engineered and hence 
can be claimed for filing a patent. After nine years of struggle, in 1980, he finally received his much deserving fame over settlement of this legal suite over patent and it was awarded to him after ruling of Supreme Court (US Patent No. 4259444 for "Microorganisms having multiple compatible degradative energy-generating plasmids and preparations thereof") (Breu 1980; Douglas 2015). In this way, he paved new gateways for bio-patenting of genetically modified microorganisms and other lifeforms and is rightfully called as 'Father of Patent Microbiology'. This also paved the way for bioremediation as a full-fledged industry. Since then, he took several advisory roles on such legal issues and served as member of many prestigious committees.

The never ending thrust for research has translated in many significant research contributions of Prof. Chakrabarty, in wide range of areas of biotechnology. Apart from his revolutionary discovery of 'bioengineered superbug', he has also achieved several other milestones including development of promiscuous bacterial protein/peptide based anticancer, anti-viral and anti-parasitic drugs. He discovered a bacterial periplasmic protein azurin from Pseudomonas aeruginosa with potent antineoplastic properties (Chakrabarty 2003, 2010). He co-founded two startup companies named CDG Therapeutics Inc., in Chicago and Amrita Therapeutics in India (https://www.cdgti.com, https://www.amritather apeutics.com $/ \mathrm{html} /$ chakrabarty.html) to develop vaccines, therapies and diagnostics specially for cancer and several other diseases. Based on his work at University of Illinois, Chicago, there are several US patents that have been issued and CDG Therapeutics Inc. holds its proprietary information. His patents on "cytoxic factors for modulating cell death" [US Patent 7084105, 791394, 7888468] showed that different pathogens possess cytotoxic factors having anticancerous properties that can be used in preventing necrosis and apoptosis related conditions during infectious disease like cancer. Another patent on "cupredoxin derived transport agents and methods of use thereof" [US Patent 7691383, 8206685, 8530635] presented the methods and materials for delivering a cargo compound into a cancer cell using protein transduction domains derived from cupredoxins. Similarly, his patent on "transport agents for crossing the blood-brain barrier and into brain cancer cells, and methods of use thereof "[US Patent 7807183, 8188251, 8545812] dealt with diagnosing and treating cancer particularly of brain as well as other brain related conditions. Another patent on "compositions and methods to control angiogenesis with cupredoxins" [US Patent 7556810, 8,124,055, 8372962] is related to the use of cupredoxins to repress the process of tumor-related angiogenesis in mammalian cells and tissues. Apart from these, there are many other patents in his name which include: compositions and methods to prevent cancer with cupredoxins [US Patent 7618939, 8227402, 8158574, 8232244], compositions and methods for treating conditions related to ephrin signaling with cupredoxins [US Patent 7381701], compositions and methods for treating HIV infection with cupredoxin and cytochrome 'c' [US Patent 7301010, 7511117, 7795410], compositions and methods for treating malaria with cupredoxin and cytochrome [US Patent 7338766, 8623816, 7740857] (https://www.cdgti .com/science-technology/patents/2.

Prof. Chakrabarty was one of the founding members of United Nations Industrial Development Organization Committee which laid foundation of International Centre for Genetic Engineering \& Biotechnology (ICGEB). He also assisted the Stockholm Environment Institute of Sweden. He was a member of NATO Industrial Advisory Group, Brussels, Belgium and member of Board of Directors of The Einstein Institute for Science Health and the Courts (EINSHAC) now known as National Courts and Sciences Institute (NCSI), United States. He was awarded as the Scientist of the Year by Industrial Research Organization of the United States in the year 1975. He also received various awards including Inventor of the Year award, Patent Lawyers' Association, 1982, Public Affairs award, American Chemical Society, 1984, Distinguished Scientist award, Environmental Protection Agency, 1985, Pasteur Award, 1991, Procter and Gamble Environmental Biotechnology Award by American Society for Microbiology (ASM). In the year 2007 for his contributions in the field of genetic engineering he was awarded Padma Shri by the Government of India (https://www.dashboard-padmaawards.gov.in/?Award $=$ Padma\%20Shri\&Year=2007-2007).

From being a policy maker for biological products to being a legal advisor to judges of Supreme Court, Prof. Anand Mohan Chakrabarty always aimed to help and serve scientific community and humankind. He strived to prioritize patent oriented research and to make biotechnological products marketable. He also emphasized that every research and development organization should establish a patent cell. An extremely gentle, down to earth person, who has been an innovative thinker, philosopher and ready to accept challenges with result oriented out-of-the-box solutions, shall always be the reflection of his personality. We hope and pray that his immortal presence shall keep on inspiring the microbiologists and scientists of all over the world, forever!

\section{References}

Breu G (1980) An Illinois biochemist wins a crucial patent fight, and a new era of life in a test tube begins. https://people.com/archive/ an-illinois-biochemist-wins-a-crucial-patent-fight-and-a-new-eraof-life-in-a-test-tube-begins-vol-14-no-2/

Chakrabarty AM (2003) Patenting life forms: yesterday, today, and tomorrow. In: Kieff FS, Olin JM (eds) Perspectives on properties 
of the human genome project. Elsevier Academic Press, Amsterdam, pp 3-11

Chakrabarty AM (2010) Bioengineered bugs, drugs and contentious issues in patenting. Bioeng Bugs 1(1):2-8

Douglas S (2015) Mr. Pseudomonas. Life sciences at CHF. https:// medium.com/lsf-magazine/mr-pseudomonas-198a5eddc47

Renneberg R, Berkling V, Loroch V (2017) Environmental biotechnology: from one-way streets to traffic circles. In: Demaine AL (ed)
Biotechnology for beginners (second edition), Elsevier, Academic Press, San Diego, United States, pp 201, 203-232

Publisher's Note Springer Nature remains neutral with regard to jurisdictional claims in published maps and institutional affiliations. 